\title{
Gender gap in the authorship of published articles in the Boletín Médico del Hospital Infantil de México
}

\author{
Karla P. Estrada-Ramírez ${ }^{1}$, América L. Miranda-Lora ${ }^{2}$, Ricardo C. Sandoval-Quiroa ${ }^{3}$, Diana Ávila-Montiel${ }^{4}$, \\ María J. Mier-Prado ${ }^{5}$ and Juan Garduño-Espinosa ${ }^{4 *}$ \\ ${ }^{1}$ Departamento de Medicina Interna; ${ }^{2}$ Unidad de Investigación en Medicina Basada en Evidencias; ${ }^{3}$ Departamento de Servicio Social; ${ }^{4}$ Dirección \\ de Investigación; ${ }^{5}$ Departamento de Pediatría. Hospital Infantil de México Federico Gómez, Mexico
}

\begin{abstract}
Background: Women's participation in medicine has increased in the last decades, with greater representativeness in the authorship of scientific articles in many countries and different specialties. The objective of this research was to analyze the gender gap in the authorship of articles through the history of the medical journal Boletín Médico del Hospital Infantil de México. Methods: In a bibliometric analysis, we reviewed original articles published during the years 1953, 1963, 1973, 1983, 1993, 2003, and 2013. The gender of the author, the type of authorship (first author or corresponding author), and the design of the study (descriptive vs. analytic) were identified. We evaluated the difference between gender proportion and trends over time. Results: We included 272 articles. We observed a gender gap reduction between 1953 and 2013. The participation of women as the first author increased from $2 \%$ to $63 \%(p<0.001)$ and as the corresponding author from $27 \%$ to $59 \%$ $(p<0.001)$. If we include only analytic studies, the increase was $25-50 \%$ as the first author $(p=0.03)$, with a similar tenden$c y$ as the corresponding author, but without a statistical significance on time $(p=0.19)$. We observed the most notable change in the 1983-1993 period. Conclusions: In the last decades, there has been a significant increase in women's authorship in the medical journal Boletín Médico del Hospital Infantil de México, even reaching a greater proportion versus the male gender. This increase reflects the present role of women in medicine, particularly in pediatrics.
\end{abstract}

Key words: Gender gap. Pediatrics. Women.

\section{Brecha de género en la autoría de artículos publicados en el Boletín Médico del Hospital Infantil de México}

\section{Resumen}

Introducción: La participación de las mujeres en medicina ha incrementado en las últimas décadas, incluyendo mayor representatividad en la autoría de artículos científicos en diversos países y distintas especialidades. El objetivo del estudio fue analizar las diferencias de género en la autoría de artículos a través de la historia del Boletín Médico del Hospital In-

Correspondencia:

*Juan Garduño-Espinosa

E-mail: juan.gardunoe@gmail.com
Available online: $23-11-2018$ Bol Med Hosp Infant Mex. 2018:75:184-191 www.bmhim.com 
fantil de México. Métodos: Se realiza. un análisis bibliométrico de los artículos originales publicados en los años 1953, 1963, 1973, 1983, 1993, 2003 y 2013. Se identificó. el género de los autores, tipo de autoría (primer autor o autor correspondiente) y el diseño de estudio (descriptivo vs. analítico). Se evaluó. la diferencia en la proporción de género y la tendencia en el tiempo. Resultados: Se incluyeron 272 artículos. Se observó. una reducción en la brecha de género entre 1953 y 2013. La participación de las mujeres como primeras autoras incrementó. del 2 al $63 \%(p<0.001)$ y como correspondiente del 27 al $59 \%(p<0.001)$. Al considerar únicamente estudios analíticos, el incremento fue del 25 al 50\% como primera autora ( $p=0.03)$, con un cambio similar como autor correspondiente, pero sin una tendencia significativa en el tiempo $(p=0.19)$. La reducción en la brecha de género fue más notoria a partir del periodo 1983-1993. Conclusiones: En las.últimas décadas ha existido un incremento significativo en la autoría de las mujeres en el Boletín Médico del Hospital Infantil de México, Ilegando incluso a una mayor proporción en relación con el sexo masculino. Lo anterior es un reflejo del papel actual de las mujeres en la medicina; en particular, en el área pediátrica.

Palabras clave: Brecha de género. Pediatría. Mujeres.

\section{Introduction}

Through the ages, the terms sex and gender have evolved according to the era or society and have been confused because of their nature.

The term sex refers to the physical, biological, and sexual characteristics of people. This term is oriented to the possibility for sexual reproduction and classifies people into men and women. However, nowadays, categories such as women, men, intersexuals (people with male and female sexual characteristics), and transsexuals (people undergoing sex-change surgeries or hormonal treatments) have been included ${ }^{1}$.

On the other hand, the term gender is a sociocultural construction that revolves around the perception of what corresponds to the ideas, norms, and behaviors that society expects or establishes to the feminine or masculine gender; meaning, it arises from a system of practices and social relations $\mathbf{s}^{1,2}$.

The sex of individuals determines gender social relations, which causes an asymmetric relationship between men and women. Consequently, a difference is established between them, where masculine activities and actions are considered more important, which, in turn, gives men greater power in society and promotes inequality against women ${ }^{2,3}$.

The women's role in professional and work environments has been increasing. However, gender inequalities persist in different areas. Mexico ranks $71^{\text {st }}$ in gender equity among 145 countries according to the 2015 Global Gender Gap Report published by the World Economic Forum, with a score of 0.70 ( $0=$ inequality, 1 = equality). In our country, the most important inequality is reported in the field of economic participation and opportunities $(\leq 0.67)$, as well as in political empowerment $(\leq 0.74)$. On the other hand, items such as educational level, health, and survival rate have reached figures of greater equity $(\geq 0.95)^{1}$.
Conventionally, the medical and scientific professions have been dominated by men. However, it is certain that the women's participation has been increasing in the recent decades. Despite the above, it has been observed that women continue to be a minority concerning the authorship of articles in various medical specialties ${ }^{2}$.

The latter may be because women who are in this guild are subordinated to a vertical structure. Although there has been an increase in the women's participation in research, the gender gap remains high ${ }^{4}$. Scientific publications are a tool for measuring academic productivity. It could be expected that the increase in the women's participation in different medical specialties would be parallel to an increase in scientific production; however, this is not always true. Some reports indicate that a gender gap persists in scientific publications in different specialties ${ }^{2-14}$ while others report a notable reduction ${ }^{7,15-17}$.

To date, there are no data about the current landscape of women's participation in article publications in Mexico, and less in the pediatric area, which has been one of the specialties where women's participation has increased markedly.

Two hypotheses have been proposed to study the causes of research inequality in the literature. The first is known as the cohort effect: it attributes inequality to the late incorporation of women into the professional field. In this theory, it is believed that equality will be achieved naturally, as more women continue to join the scientific field ${ }^{5,6,18}$.

The second hypothesis is called the glass ceiling and points to the patriarchal social structure as the cause of the difficulties that women face to achieve high-rank positions, even when there are laws that promote gender equity ${ }^{19}$.

The Hospital Infantil de México Federico Gómez has been interested in the generation and diffusion of 
knowledge through its medical journal, the Boletín Médico del Hospital Infantil de México (BMHIM). This journal has more than 70 years of disseminating knowledge in the pediatric area in an uninterrupted manner, both in Mexico and in other Latin American countries. Therefore, the objective of the present study was to analyze the gender differences in the articles authorships throughout the history of the BMHIM.

\section{Methods}

A bibliometric study was carried out in which works identified as original and editorial articles published in 1953, 1963, 1973, 1983, 1993, 2003, and 2013 in the BMHIM were included. It was also reviewed the editorial committee conformation during these years and its disposition according to the divisions by specialty areas.

Narrative reviews, comments, and letters to the editor were excluded from the study. The authors' gender, type of authorship (first author or corresponding author), and design of the study (descriptive vs. analytical) were identified. It is worth mentioning that editorial articles were included since they are made by an editorial committee request. In this sense, it is important to know how many of these articles were ordered for men and the same to women.

The gender identification was carried out by two independent evaluators, who considered the following aspects:

- Names related to a single genre. For example, Federico corresponds to a man and Aída corresponds to a woman.

- Gender identification in the professional title. For example, Dr. or Dra. (a term used in Spanish for female doctors).

- When the author's gender could not be defined in the initial assessment, since only the initials were used or the name was not related only to one gender (for example, "Guadalupe"), an exhaustive search was carried out on the Internet in personal sites, institutions, or previous publications, in the attempt to define the author's genre.

- In some cases, colleagues were consulted to corroborate the authors' gender. We excluded the articles in which, despite these measures, the gender was not identified.

The first author was identified as the first name that appears in the list of authors, and the corresponding author was identified according to the contact data for the correspondence of each article. In articles with a single author, this was identified as both the first author and the corresponding author.

Concerning the study design, analytical studies were considered those studies in which there was a comparison group (cross-sectional analytical study, case-control, cohort, and clinical trials); non-analytical studies were those in which only a descriptive analysis of the data was included (descriptive cross-sectional study, series of cases).

The original articles were characterized using descriptive statistics (absolute and relative frequencies). The gender proportion in each of the evaluated years was calculated according to the authorship type and study design. The Cochran-Armitage test for trend was conducted to evaluate the gender ratio trend over time. The statistical program STATA SE v11.0 was used and $p<0.05$ was considered statistically significant. As for the editorial articles, the editorial committee composition over the years and the subdivisions by specialty areas were characterized using descriptive statistics, the latter to know the number of editorial articles published by each gender, as well as the editorial committee composition and its specialty areas.

\section{Results}

We identified 275 research articles in the included volumes, of which one article was excluded because it was not possible to identify the authors and two articles in which the genre could not be determined, using a total of 272 articles in the final analysis (98.9\%).

Table 1 shows the total number of articles, the number of analytical studies, and the percentage of women as the first author and corresponding author per year of publication. These data show an increase in the proportion of women as the first authors from $2 \%$ to $63 \%$ and as corresponding authors from $27 \%$ to $59 \%$ over time.

In 1953, the male-female ratio in the first authorship was $49: 1$; this proportion gradually changed until it became equivalent in 2003 and was reversed in 2013, with a $0.6: 1$ ratio. Regarding the corresponding authorship, the ratio was inverted from 2.7:1 in 1953 to $0.7: 1$ in 2013. As shown in figure 1, the women's participation in the authorship increased significantly in the period of 1983-1993 ( $p<0.001)$.

Considering only analytical studies, the male-female ratio as the first author remained in favor of the male gender during the period of 1953-1993, with a 2.5-9:1 ratio (Fig. $1 \mathrm{C}$ and $\mathrm{D}$ ). The reduction of the gap was observed since 2003, and a 1:1 ratio was reached in 
Table 1. Number of total articles, frequency of analytical studies, and percentage of women's authorship by the year of publication.

\begin{tabular}{|l|c|c|c|c|c|c|}
\hline Years & $\begin{array}{c}\text { Number } \\
\text { of total } \\
\text { articles }\end{array}$ & $\begin{array}{c}\text { Number of } \\
\text { women as the } \\
\text { first authors }\end{array}$ & $\begin{array}{c}\text { Number of women } \\
\text { as corresponding } \\
\text { authors }\end{array}$ & $\begin{array}{c}\text { Number of total } \\
\text { analytical } \\
\text { studies }\end{array}$ & $\begin{array}{c}\text { Number of women } \\
\text { as the first authors } \\
\text { in analytical studies }\end{array}$ & $\begin{array}{c}\text { Number of women as } \\
\text { corresponding authors } \\
\text { in analytical studies }\end{array}$ \\
\hline 1953 & $\mathbf{n}$ & $\mathbf{n}(\%)$ & $\mathbf{n}(\%)$ & $\mathbf{n}$ & $\mathbf{n}(\%)$ & $\mathbf{n}(\%)$ \\
\hline 1963 & 45 & $1(2)$ & $12(27)$ & 4 & $1(25)$ & $1(25)$ \\
\hline 1973 & 29 & $1(3)$ & $4(13)$ & 10 & $1(10)$ & $3(30)$ \\
\hline 1983 & 32 & $4(14)$ & $6(21)$ & 11 & $3(27)$ & $4(36)$ \\
\hline 1993 & 66 & $19(29)$ & $14(21)$ & 43 & $2(11)$ & $1(5)$ \\
\hline 2003 & 36 & $18(50)$ & $13(36)$ & 25 & $12(28)$ & $7(16)$ \\
\hline 2013 & 32 & $20(63)$ & $19(59)$ & 22 & $14(56)$ & $11(44)$ \\
\hline Total & 272 & $67(25)$ & $70(26)$ & 134 & $44(33)$ & $11(50)$ \\
\hline
\end{tabular}

$2013(p=0.031)$. Although an inversion of the male-female ratio as the corresponding author of the analytical articles was also observed, these changes did not show statistical significance during the period studied $(p=0.195)$.

Regarding the composition of the editorial committee for the years 1953, 1963, 1973, 1983, 1993, 2003, and 2013 , it was observed that no woman was part of the committee until 2013. In that year, the editorial committee was formed by $86 \%$ of men and $14 \%$ of women (Fig. 2).

Since 2013, the editorial committee was divided into eight specialty areas (biomedical, public health, pediatric issues, health education, clinical ethics, clinical cases, clinical epidemiology, and clinicopathological cases). It was observed that in six of these areas (biomedical, pediatric issues, health education and clinical ethics, clinical cases, clinical epidemiology, and clinicopathological cases), men predominated in $100 \%$, while in the area of public health, women predominated in the same way in $100 \%$. Regarding the clinical area, we found that it is equitably composed by $50 \%$ of men and $50 \%$ of women (Fig. 3).

Regarding editorial publications, it is important to mention that these types of articles are requested by the editorial committee. In 2013, for the $1^{\text {st }}$ time, an editorial article was commissioned to a woman (Fig. 4).

\section{Discussion}

In the history of humankind, the man-woman dichotomy has led to the establishment of stereotypes that have conditioned and limited the potential of one or the other genders in different fields. Global efforts to achieve an equal distribution of resources and opportunities between men and women have made it possible to reduce the gender gap. However, equality has not been achieved in all areas, that is, why differences are still observed on a global scale'.

To the best of our knowledge, this is the $1^{\text {st }}$ time that the gender ratio of medical articles production in Mexico has been evaluated. There has been an evident increase in the women's participation in the authorship of original articles in the BMHIM. Therefore, the gender gap decrease in authorship could be a reflection of the women's progress in the medical and research areas ${ }^{20}$.

There is no doubt that, in general, the women's participation in the authorship of scientific articles has increased worldwide. However, the gender gap persists in most of the studies, and usually, there is not a report of women superiority in the proportion of authorship, such as the one identified in the BMHIM publications in recent years.

One of the most important studies in which the authorship gender gap in scientific journals was evaluated was published by Jagsi et al. ${ }^{2}$ In this study, six high-impact journals published in the United States were analyzed. The study reported an increase from $5.9 \%$ in 1970 to $29.3 \%$ in $2004(p<0.001)$ in the women's authorship as the first author, and as principal or senior author from $3.7 \%$ to $19.3 \%(p<0.001)$. A similar picture was reported in the United Kingdom ${ }^{12}$.

Other studies have also reported an increase in the women's participation in the authorship of articles, with figures close to $30 \%$ in the recent decades $3,6,7,9,10,15$, and even in the most recent study, a figure of $37 \%$ was reported $^{13}$. Despite the above, most studies conclude 


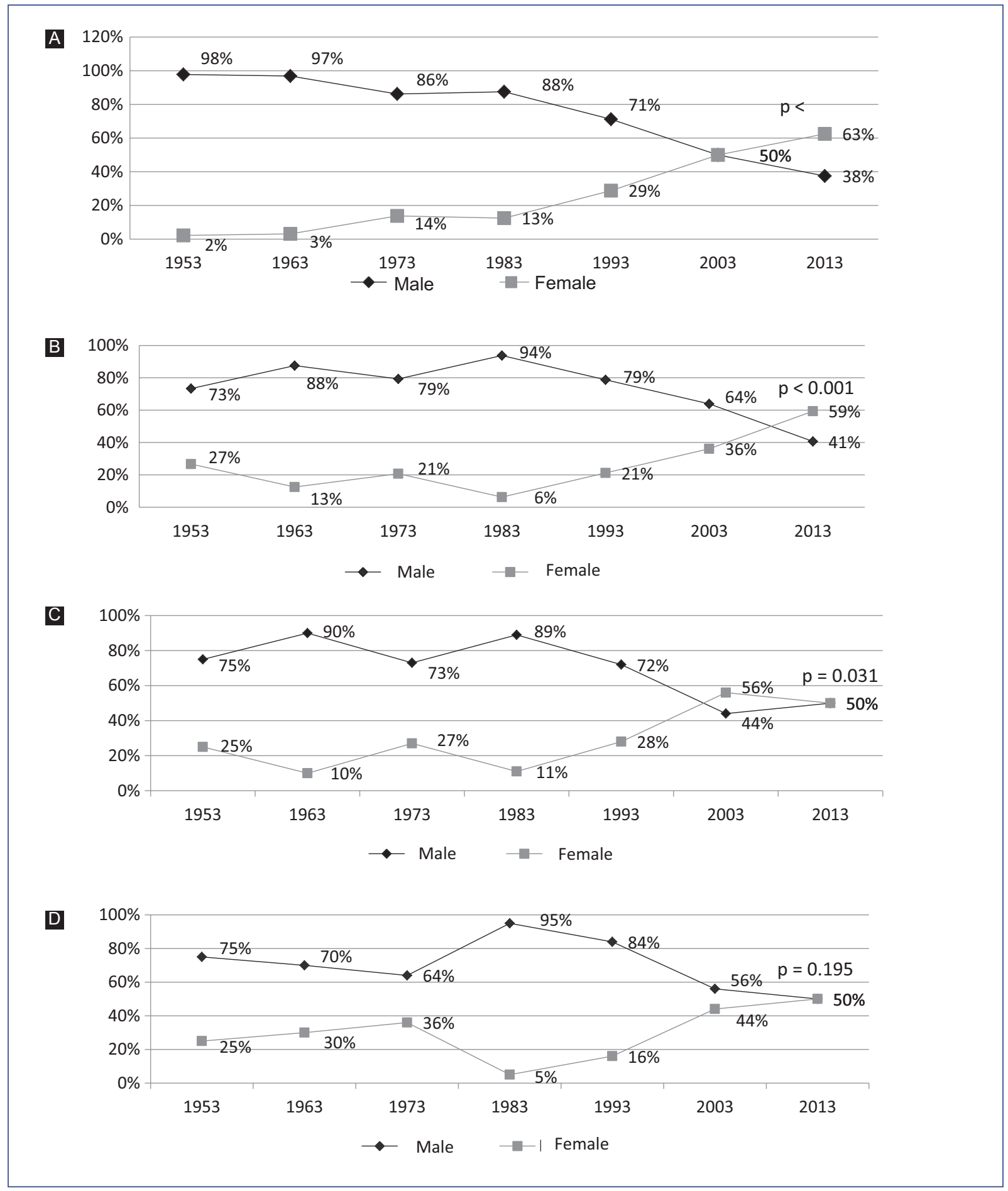

Figure 1. Gender tendency as the first author (A) and corresponding author (B), as well as in analytical studies concerning the first author (C) and the corresponding author (D) over time in articles published in the Boletín Médico del Hospital Infantil de México.

that the women's participation as authors is still lower compared to men, especially concerning areas related to surgery ${ }^{4,14,17}$, which has been linked to lower participation of women in surgical specialties.
In the specific analysis of pediatric journals, women's participation as authors has increased, reaching figures between $38.9 \%$ and $53.2 \%$ as the first authors, and between $27.8 \%$ and $38.0 \%$ as senior authors in the first 


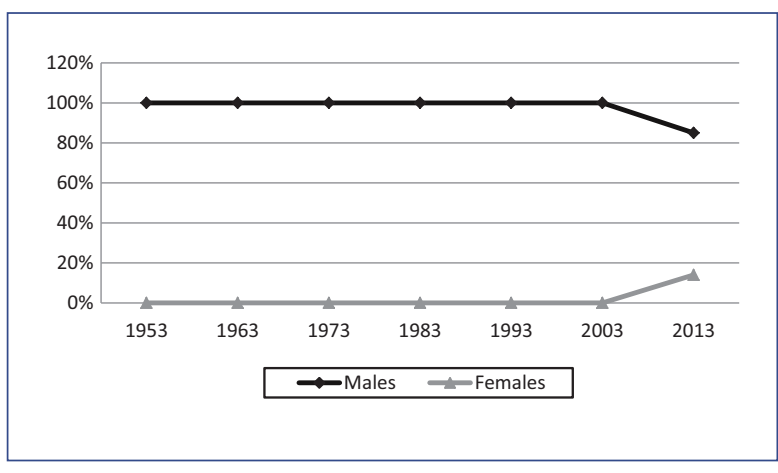

Figure 2. Editorial committee confirmation over the years.

decade of the $21^{\text {st }}$ century ${ }^{2,12}$. Although this percentage seems favorable, it should be considered that pediatrics is one of the preferred specialties for women (2-3 women for every man) so that a higher proportion of women in authorship within this specialty would be expected $^{21}$.

If we consider that the women's ratio in the medical residency programs at the Hospital Infantil de México Federico Gómez currently reaches $65.7 \%$ and that of researchers is $50.5 \%$, the women's authorship proportion would be reaching a similar ratio ( 60\%). These results seem consistent with the increase in the women's participation in the workforce of the pediatric field, which reflects a condition of equity between both genders.

Although cases have been reported where the women's scientific production exceeds their proportional participation in the workforce ${ }^{17}$, there are other medical fields in which a greater women's participation is not reflected in a higher ratio of scientific production. As the case of the nursing field, traditionally dominated by women (>90\%), but with a non-proportional ratio in scientific production $(<70 \%)^{8}$.

As previously mentioned, most studies agree that despite its increase, women's participation continues to be small22. Within the explanations of what has been observed in the rest of the world, there are issues related to work and life goals differences; that is, the role that men and women must play according to their gender stereotype determined by society. A role that labels women as the main responsible for the children upbringing and care of the house and that positions the man as the provider, so he has more possibilities for work development, coinciding with the hypothesis called "glass ceiling"19.

It has been pointed out that academic success in the medical field requires a significant time investment, which becomes incompatible with the children's care; women who are mothers, apparently publish less and have less institutional support compared to male coIleagues with children ${ }^{23}$. It has also been pointed out that, in general, academic success in medicine requires $70 \mathrm{~h}$ of work per week ${ }^{24}$, which may be incompatible with personal life challenges.

Conversely, the present results indicated a reversal in the male-female participation ratio as the first author and corresponding author. The explanation of these results concerning whether women in Mexico also presents family and personal challenges that hinder academic development could generate different hypotheses. Among the possible explanations that could be proposed, there is an increased interest of women in the medical and research fields, a lower priority to issues related to motherhood and family, greater equality in work conditions, or a reduction in gender discrimination. All of these situations have been previously identified as possible barriers to the adequate representation of women in academic and scientific fields ${ }^{23,25}$.

On the other hand, a gender gap in the opposite direction, that is, a lower proportion of scientific production by the male gender would also contradict the principle of gender equality that has been advocated in the recent years. Analyzing the other side of the coin, the decrease in the men authorship ratio of scientific articles could reflect a lesser interest in the medical and research fields, which may be partly because these fields encompass long careers in which productivity begins at an older age, and financial remuneration may not correspond to the effort required to obtain academic success.

Despite the above, we recognize as a limitation that we only performed the analysis of a small part of the knowledge in the pediatric field generated in the country. Moreover, the male-female participation ratio in other means of scientific dissemination that could have a higher academic impact or that could represent other types of academic positions of greater leadership is unknown.

Another limitation of the present work was that it focused on a single journal and did not include all the years of publication, so our results may not reflect the totality of pediatric research in Mexico and much less of other specialties. Furthermore, the low representativeness of the types of articles with higher scientific evidence published in the BMHIM (clinical trials, meta-analysis) did not allow us to explore in detail the women's progress in this type of scientific studies. Finally, when an author's genre could not be defined 


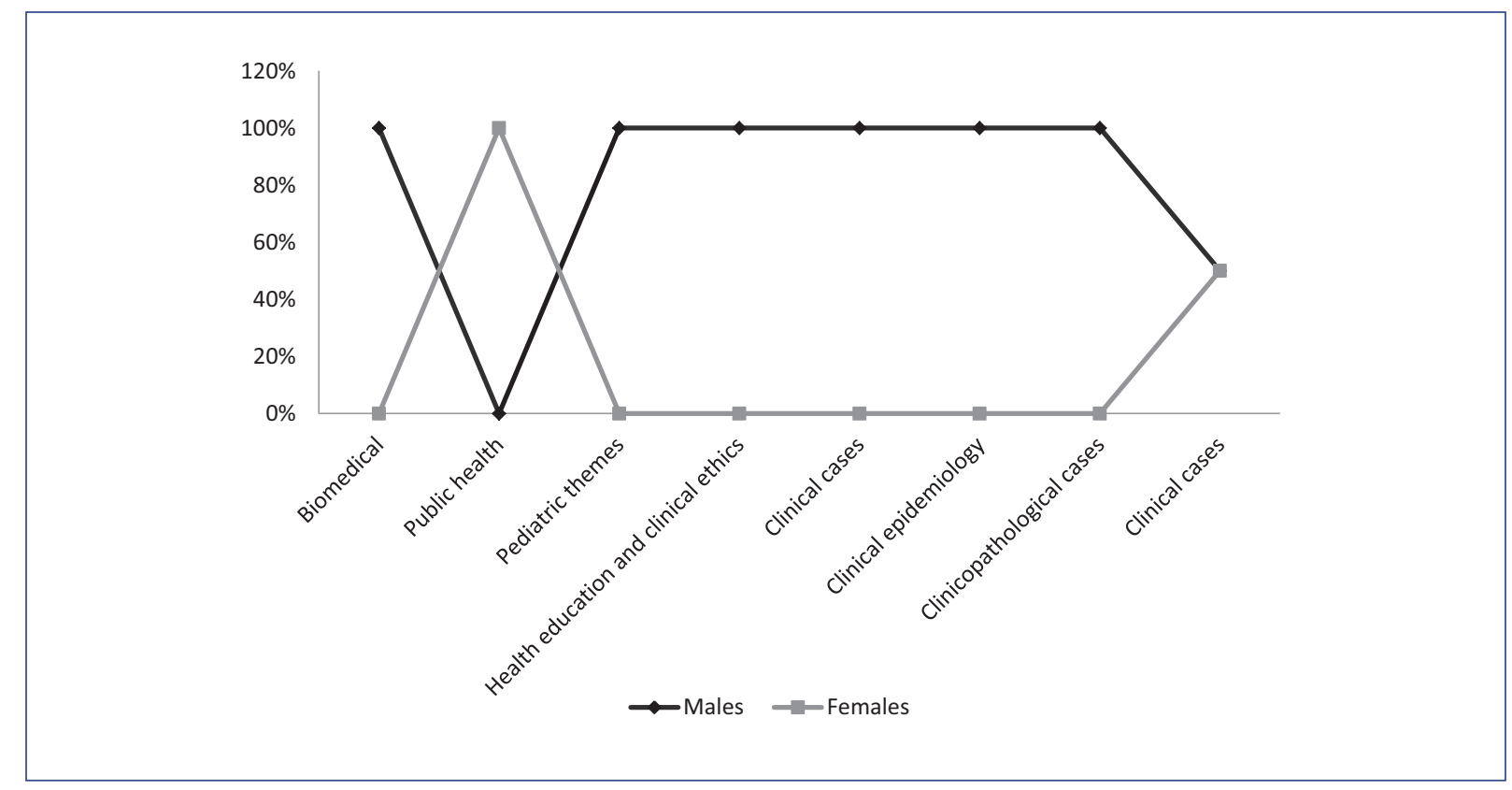

Figure 3. Editorial committee composition in 2013 by specialty area.

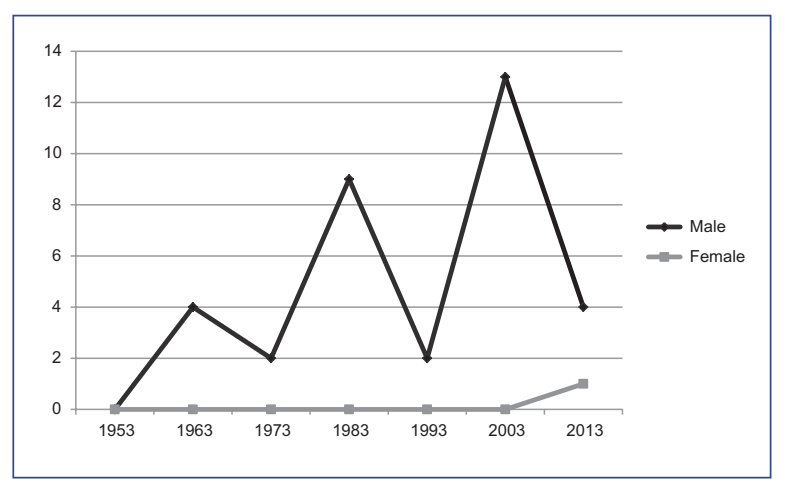

Figure 4. Editorial articles.

during the assessment, an exhaustive search was carried out by other means, which might not be ideal to determine the author's sex.

In conclusion, in the recent decades, there has been a significant increase in the women's authorship in the BMHIM, reaching even a higher authorship proportion compared to males. The above is a reflection of the current role of women in medicine, particularly in the pediatric field. However, although it is true that progress has been made in gender equity, there is still work to be done regarding the stereotypes that determine the roles of the feminine and the masculine. Therefore, it is essential to consider both men and women capable of performing the same functions in the scientific, labor, and personal fields.

\section{Ethical disclosures}

Protection of humans and animal subjects. The authors declare that no experiments have been conducted on humans or animals for this research.

Confidentiality of data. The authors declare that they have followed the protocols of their work center on the publication of patient data.

Right to privacy and informed consent. The authors declare that no patient data appear in this article.

\section{Funding}

None.

\section{Conflicts of interest}

The authors declare no conflict of interest.

\section{References}

1. The Global Gender Gap Report 2015. World Economic Forum (2015). Available at: http://reports.weforum.org/global-gender-gap-report-2016/.

2. Jagsi R, Guancial EA, Worobey CC, Henault LE, Chang Y, Starr R, et al. The "gender gap" in authorship of academic medical literature-a 35-year perspective. N Engl J Med. 2006;355(3):281-7.

3. Amering M, Schrank B, Sibitz I. The gender gap in high-impact psychiatry journals. Acad Med. 2011;86(8):946-52.

4. Bergeron JL, Wilken R, Miller ME, Shapiro NL, Bhattacharyya N. Measurable progress in female authorship in otolaryngology. Otolaryngol Head Neck Surg. 2012;147(1):40-3.

5. Dewan P, Gupta P, Choudhury P. Gender gap and Indian Academy of Pediatrics: still a long way to go! Indian Pediatr. 2007;44(8):598-600. 
6. Özlem EA, Elçin ÖE, Ece U. Longitudinal analysis of female authorship of psychiatry articles in Turkey. Arch Neuropsychiatr. 2015;52:95-8.

7. Schrager S, Bouwkamp C, Mundt M. Gender and first authorship of papers in family medicine journals 2006-2008. Fam Med. 2011:43(3):155-9.

8. Shields L, Hall J, Mamun AA. The 'gender gap' in authorship in nursing literature. J R Soc Med. 2011;104(11):457-64.

9. Yun EJ, Yoon DY, Kim B, Moon JY, Yoon SJ, Hong SJ, et al. Closing the gender gap: increased female authorship in AJR and Radiology. AJR Am J Roentgenol. 2015;205(2):237-41.

10. Takayanagui OM, Livramento JA. The increasing female participation in authorship of articles published in neurology in Brazil. Arq Neuropsiquiatr. 2009;67(3b):914-6.

11. Shah DN, Huang J, Ying GS, Pietrobon R, O'Brien JM. Trends in female representation in published ophthalmology literature, 2000-2009. Digit J Ophthalmol. 2013:19(4):50-5.

12. Sidhu R, Rajashekhar P, Lavin VL, Parry J, Attwood J, Holdcroft A, et al. The gender imbalance in academic medicine: a study of female authorship in the United Kingdom. J R Soc Med. 2009;102(8):337-42.

13. Filardo G, da Graca B, Sass DM, Pollock BD, Smith EB, Martinez MA. Trends and comparison of female first authorship in high impact medical journals: observational study (1994-2014). BMJ. 2016;352:i847.

14. Kurichi JE, Kelz RR, Sonnad SS. Women authors of surgical research. Arch Surg. 2005;140(11):1074-7.

15. Feramisco JD, Leitenberger JJ, Redfern SI, Bian A, Xie XJ, Resneck JS, $\mathrm{Jr}$. A gender gap in the dermatology literature? Cross-sectional analysis of manuscript authorship trends in dermatology journals during 3 decades. J Am Acad Dermatol. 2009;60(1):63-9.
16. Tinjum BE, Getto L, Tiedemann J, Marri M, Brodowy M, Bollinger M, et al. Female authorship in emergency medicine parallels women practicing academic emergency medicine. J Emerg Med. 2011;41(6):723-7.

17. Weiss DA, Kovshilovskaya B, Breyer BN. Gender trends of urology manuscript authors in the United States: a 35-year progression. J Urol. 2012;187(1):253-8.

18. Borrel C, Vives-Cases C, Domínguez-Berjón M, Álvarez-Dardet C. Las desigualdades de género en la ciencia: Gaceta Sanitaria da un paso adelante. Gac Sanit. 2015;29(3):161-3.

19. Colomer RC, Peiró PR. ¿Techos de cristal y escaleras resbaladizas? Desigualdades de género y estrategias de cambio en SESPAS. Gac Sanit. 2002;16(4):358-60.

20. Miller K. Policy and organizational implications of gender imbalance in the NHS. J Health Organ Manag. 2007;21(4-5):432-47.

21. Lambert EM, Holmboe ES. The relationship between specialty choice and gender of U.S. medical students, 1990-2003. Acad Med. 2005;80(9):797-802.

22. S. Tornero P. Necesidad de la perspectiva de género en el anuario de Anales de Pediatría. An Pediatr. 2015; 83:225

23. Carr PL, Ash AS, Friedman RH, Scaramucci A, Barnett RC, Szalacha L, et al. Relation of family responsibilities and gender to the productivity and career satisfaction of medical faculty. Ann Intern Med. 1998;129(7):532-8.

24. Hamel MB, Ingelfinger JR, Phimister E, Solomon CG. Women in academic medicine-progress and challenges. N Engl J Med. 2006;355(3):310-2.

25. Edmunds LD, Ovseiko PV, Shepperd S, Greenhalgh T, Frith P, Roberts NW, et al. Why do women choose or reject careers in academic medicine? A narrative review of empirical evidence. Lancet. 2016;388(10062):2948-58. 